\title{
Originals
}

\section{S15261, a new compound for the treatment of the insulin resistance syndrome}

\author{
J.Duhault ${ }^{1}$, F. Lacour ${ }^{1}$, M. Boulanger ${ }^{1}$, O. Della-Zuana ${ }^{1}$, D. Ravel ${ }^{1}$, M. Wierzbicki $^{2}$ J. Espinal $^{1}$ \\ ${ }^{1}$ Division of Metabolic Diseases, Institut de Recherches Servier, Suresnes, France \\ ${ }^{2}$ Division of Chemistry, Institut de Recherches Servier, Suresnes, France
}

Summary A new oral agent, S15261 (the L-isomer of 3[2- [2- [4- [2- [ $\alpha$-fluorenyl acetyl amino ethyl] benzoyloxy] ethyl amino] 1-methoxy ethyl] trifluoromethylbenzene), has been developed for the treatment of the so-called "insulin resistance syndrome". In obese, insulin-resistant ageing Sprague-Dawley rats, chronic treatment with S15261 $\left(0.5-2.5 \mathrm{mg} \cdot \mathrm{kg}^{-1} \cdot\right.$ day $^{-1}$ twice per day, for 14 days) resulted in dose-dependent decreases in plasma insulin ( $43 \%$ ), and triglyceride levels $(36 \%)$, and in an increase of the glucose disposal rate during an intravenous glucose tolerance test (IVGTT) $(48.5 \%)$. An increase in peripheral insulin sensitivity produced by $\$ 15261$ was revealed by the glucose clamp technique. Thus, the glucose infusion rate was increased by $20 \%$ whilst steady-state insulin levels decreased by $15 \%$. At the higher doses S15261 led to a decrease in body weight ( $3 \%$ ), plasma glucose $(13 \%)$ and blood pressure $(8 \mathrm{~mm} \mathrm{Hg})$ in mildly hypertensive animals. At the doses used to achieve these results, the compound has no hypoglycaemic activity in normoglycaemic animals. Acute administration of S15261 directly into the portal vein provoked a marked increase in glucose disappearance rate during an intravenous glucose tolerance test $(60 \%)$ and also in the pancreatic response to the glucose challenge. Thus, acute administration of the compound has a direct effect on glucose metabolism. These data suggest that $\mathrm{S} 15261$ could be a useful agent for the treatment of the insulin resistance syndrome. [Diabetologia (1994) 37:969-975]

Key words S15261, insulin resistance, ageing, syndrome X.
Insulin resistance, and its counterpart hyperinsulinaemia, are characteristic features of not only NIDDM and obesity but also essential hypertension, hyperlipidaemia, atherosclerosis, and the normal ageing process $[1-4]$. Moreover, even within the normal healthy

Part of this work was presented at the $52^{\text {nd }}$ Meeting of the American Diabetes Association, San Antonio, Texas, 1992

Received: 23 December 1993

and in revised form: 28 April 1994

Corresponding author: Dr. J. Duhault, Division of Metabolic Diseases, Institut de Recherches Servier, 11, Rue des Moulineaux, F-92150 Suresnes, France

Abbreviations: IVGTT, Intravenous glucose tolerance test; $\mathrm{K}_{\mathrm{G}}$, glucose disappearance rate; NIDDM, non-insulin dependent diabetes mellitus; GIR, glucose infusion rate; SSIL, steady-state insulin levels; ANOVA, analysis of variance; $\mathrm{Ra}$, glucose appearance; HGP, hepatic glucose production. population there is a significant percentage of individuals (as high as $20 \%$ ) who are insulin resistant and exhibit the same profile of risk factors as obese or diabetic patients. In the last few years, this collection of cardiovascular risk factors has been given a variety of names, including syndrome $\mathrm{X}$, insulin resistance syndrome, atherothrombogenic syndrome, or metabolic cardiovascular syndrome.

Drugs to treat some of the features of the insulin resistance syndrome do exist, for example, lipid lowering agents or antihypertensive drugs. However, their effect on insulin resistance itself are varied. Whilst lipid lowering agents have little or no effect on glucose tolerance, antihypertensive agents can either improve it (e.g. the ACE inhibitors [5]) or decrease it (e.g. thiazide diuretics [6]). No drugs are currently being marketed for the treatment of insulin resistance and indeed very few agents are being clinically studied for this condition. Whilst biguanides do 


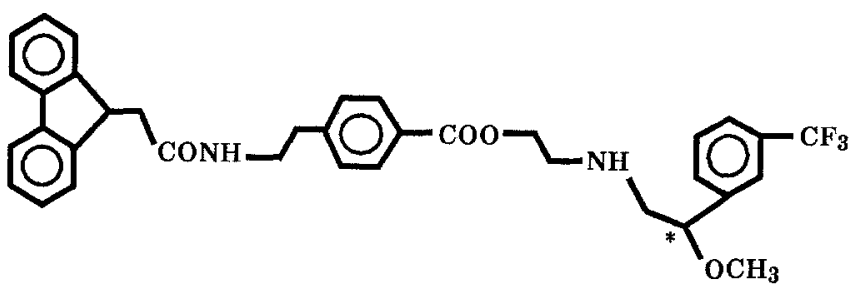

Fig. 1. S15261. The asterisk indicates the asymetric carbon

improve glucose tolerance, it is not clear whether they actually ameliorate insulin resistance [7]. The thiazolidinediones are the only new class of agents that have actually been shown to increase insulin sensitivity in insulin-resistant animals [8], but few of these drugs have been evaluated clinically. Using one of our lipid lowering agents [9] as our starting point we screened compounds of a similar chemical class which led us to the identification of a new compound, S15261 (Fig. 1).

This present study describes the effects of S15261 on glucose tolerance and metabolism, insulin resistance, and blood pressure. We used the ageing Sprague-Dawley rat as our animal model since these rats are overweight, hypertriglyceridaemic, hypercholesterolaemic, glucose intolerant and insulin resistant [10-12]. In addition, we have recently shown that these animals are mildly hypertensive [13].

\section{Materials and methods}

Animals. Male Sprague-Dawley rats (Charles-River, Evreux, France) were purchased at 3 months of age and raised in our laboratories until a year of age. They were maintained at a constant temperature $\left(21^{\circ} \mathrm{C}\right)$ with a 12 -h artificial light cycle (07.00-19.00 hours). The animals had free access to water and standard laboratory chow (AO3, UAR Laboratory Chow, Epinay, Villemuisson, France).

We have previously observed that the level of insulin resistance and dyslipidaemia in these animals differs if they are purchased at 1 year of age or if they are raised in our laboratory and fed ad libitum for 7-12 months. The use of "maintenance" diets probably decreases, delays or prevents the onset of insulin resistance (Duhault and Boulanger, unpublished observations).

Rats of 3 months or 1 year of age, weighing on average 350 and $800 \mathrm{~g}$, respectively, were accustomed to manipulation by daily gavage with gum tragacanth $(20 \%)$ for two weeks prior to drug treatment. Body weight was measured daily. All experimental procedures were approved by the Comité d'Ethique de I'Institut de Recherches Servier.

Biological parameters. Glucose, lactate, triglycerides, and cholesterol were measured in a COBAS Mira $S$ analyser (Roche Diagnostic Systems, Neuilly-sur-Seine, France) according to the manufacturer's instructions. Insulin was measured by radioimmunoassay using a Phasedeph kit (Kabi Pharmacia Diagnostics, St. Quentin-en-Yvelines, France).

S15261. S15261 is the L-isomer of 3- [2- [2- [4- [2- [ $\alpha$-fluoreny] acetyl amino ethyl] benzoyloxy] ethyl amino] 1-methoxy ethyl] trifluoromethyl-benzene (Fig.1). S15261 was administered in gum tragacanth (20\%) twice daily (10.00 and 16.00 hours), at the doses indicated in the text, for 2 weeks. Control animals received gum tragacanth alone.

Chronic study. On treatment day 13, the rats were anaesthetised with ketamine (Imalgene, $150 \mathrm{mg} / \mathrm{kg}$ i.p.; Rhone Merieux, Lyon, France), a jugular catheter was implanted and a blood sample was obtained to measure triglyceride and cholesterol Ievels. On day 14 the rats were starved overnight $(18 \mathrm{~h})$ and an IVGTT was performed the following morning by glucose injection $(500 \mathrm{mg} / \mathrm{kg}$ ) followed by serial blood sampling for $30 \mathrm{~min}$. The rate of glucose disappearance $\left(\mathrm{K}_{\mathrm{G}}\right)$ during the IVGTT is the slope of the decrease calculated by mean square deviations.

Portal infusion. Ten days before the study, rats were anaesthetized with ketamine. Silastic catheters $(0.20 \mathrm{~mm}$ internal diameter) were then positioned in the hepatic portal vein [14] for subsequent infusion of S15261 or control solutions. Each rat was fitted with a cardiac catheter 2 days prior to the study. Animals were fasted during the $18 \mathrm{~h}$ preceding the study, which was undertaken in two phases: phase 1 , consisting of a 1 -h portal infusion with saline $(0.9 \% \mathrm{NaCl})$ on day zero; and, after 3 days (during which the animals were fed ad libitum), phase 2, comprising a 1-h portal infusion of $\$ 15261$. These portal infusions were conducted between 09.00 and 11.30 hours in free-moving animals, and delivered at a constant rate of $0.035 \mathrm{ml} / \mathrm{min}$ (Braun spring pumps, Roucaire, Velizy, France) providing total doses of $\mathrm{S} 15261$ of 15,30 , and $45 \mu \mathrm{g} / \mathrm{kg}$ per $\mathrm{h}$. During each of the two phases an IVGTT was performed, as above, 30 min after beginning the portal infusion. The portal infusion was maintained 30 min after the administration of the glucose load.

Glucose clamp. The rats were anaesthetised with pentobarbital $(40 \mathrm{mg} / \mathrm{kg}$, i.p. $) 4$ days prior to the study and underwent surgical placement of a heart catheter (polyethylene tubing $0.58-\mathrm{mm}$ internal diameter, Biotrol ED 3403; Biotrol, Paris, France) via the jugular vein, for insulin and glucose infusion, and a left carotid artery catheter for glucose sampling. Food was removed $5 \mathrm{~h}$ before the study. A euglycaemic, hyperinsulinaemic clamp was performed in freely-moving animals according to previously-described procedures $[15,16]$ with minor modifications.

Hepatic glucose production was assessed by a bolus injection of $3 \mu \mathrm{Ci}$ of $3-{ }^{3} \mathrm{H}$-D-glucose (NEN, Les Ulis, France), as described by Kergoat and Portha [17], and is expressed in $\mu \mathrm{mol} \cdot \mathrm{kg}^{-1} \cdot \mathrm{min}^{-1}$. Total $\mathrm{Ra}$ was calculated using Steele's equation [18]. The exogenous GIR is expressed as umol . $\mathrm{kg}^{-1} \cdot \min ^{-1}$. SSIL are the mean of plasma insulin concentrations (nmol/l) measured at 60,70 and $90 \mathrm{~min}$ after the beginning of the insulin infusion. Insulin clearance rate is expressed as $\mathrm{ml} \cdot \mathrm{kg}^{-1} \cdot \mathrm{min}^{-1}$, and was calculated according to De Fronzo et al. [19].

Blood pressure measurement. Conscious animals were placed in plexiglass cages $30 \mathrm{~min}$ prior to the study, maintained at ambient temperature, and allowed to move freely. Mean blood pressure $(\mathrm{mm} \mathrm{Hg})$ was measured by means of a carotid catheter with a P10-EZ gauge and a Gould recorder (both from Gould Electronique, Ballainvilliers, France).

Enzymatic and metabolite determinations. Hepatic glycogen content was measured as described by Van de Werve et al. [20]. Glycogen phosphorylase and glycogen synthase activities were measured by the method of Golden et al. [21]; hexokinase and glucokinase activities were measured as described by Van Schaftingen [22]. 
Table 1. Effects of chronic administration of S15261 on metabolic parameters in old Sprague-Dawley rats

\begin{tabular}{|c|c|c|c|c|c|c|c|}
\hline & $\begin{array}{l}\text { Initial body } \\
\text { weight (g) }\end{array}$ & $\begin{array}{l}\text { Body weight } \\
\text { variation } \\
\text { (Day 1-14) (g) }\end{array}$ & $\begin{array}{l}\text { Glucose } \\
(\mathrm{mmol} / \mathrm{l})\end{array}$ & $\begin{array}{l}\text { Insulin } \\
\text { (pmol/l) }\end{array}$ & $\mathrm{K}_{\mathrm{G}}\left(\times 10^{-2}\right)$ & $\begin{array}{l}\text { Triglyceride } \\
\text { (mg/dl) }\end{array}$ & $\begin{array}{l}\text { Cholesterol } \\
\text { (mmol/1) }\end{array}$ \\
\hline Controls $(n)$ & $\begin{array}{l}801 \pm 20 \\
(25)\end{array}$ & $\begin{array}{l}-4 \pm 6 \\
(25)\end{array}$ & $\begin{array}{l}5.3 \pm 0.2 \\
(21)\end{array}$ & $\begin{array}{l}174 \pm 13 \\
(20)\end{array}$ & $\begin{array}{l}3.3 \pm 0.2 \\
(21)\end{array}$ & $\begin{array}{l}189 \pm 16 \\
(24)\end{array}$ & $\begin{array}{l}1.9 \pm 0.1 \\
(24)\end{array}$ \\
\hline $\begin{array}{l}\mathrm{S} 15261 \\
(0.5 \mathrm{mg} / \mathrm{kg} \\
2 \times \text { daily })(n)\end{array}$ & $\begin{array}{l}794 \pm 26 \\
(18)\end{array}$ & $\begin{array}{l}+10 \pm 3 \\
(18)\end{array}$ & $\begin{array}{l}5.1 \pm 0.2 \\
(15)\end{array}$ & $\begin{array}{l}149 \pm 14 \\
(14)\end{array}$ & $\begin{array}{l}4.7 \pm 0.4 \\
(16)^{\mathrm{b}}\end{array}$ & $\begin{array}{l}136 \pm 17 \\
(16)^{a}\end{array}$ & $\begin{array}{l}1.5 \pm 0.1 \\
(16)^{a}\end{array}$ \\
\hline $\begin{array}{l}\mathrm{S} 15261 \\
(2.5 \mathrm{mg} / \mathrm{kg} \\
2 \times \text { daily })(n)\end{array}$ & $\begin{array}{l}796 \pm 21 \\
(18)\end{array}$ & $\begin{array}{l}-23 \pm 2 \\
(18)^{c}\end{array}$ & $\begin{array}{l}4.6 \pm 0.1 \\
(12)^{b}\end{array}$ & $\begin{array}{l}99 \pm 10 \\
(11)^{c}\end{array}$ & $\begin{array}{l}4.9 \pm 0.4 \\
(12)^{c}\end{array}$ & $\begin{array}{l}120 \pm 17 \\
(15)^{\mathrm{b}}\end{array}$ & $\begin{array}{l}1.5 \pm 0.1 \\
(15)^{\mathrm{a}}\end{array}$ \\
\hline
\end{tabular}

S15261 was administered orally at the doses indicated twice a day for 14 days. Statistical significance is indicated by: ${ }^{\text {a }} p<0.05$; ${ }^{\mathrm{b}} p<0.01 ;{ }^{\mathrm{c}} p<0.001$ vs controls

Table 2. Effects of chronic administration of S15261 on metabolic parameters in young Sprague-Dawley rats

\begin{tabular}{|c|c|c|c|c|c|c|c|}
\hline & $\begin{array}{l}\text { Initial body } \\
\text { weight }(g)\end{array}$ & $\begin{array}{l}\text { Body weight } \\
\text { variation } \\
\text { (Day } 1-14)(\mathrm{g})\end{array}$ & $\begin{array}{l}\text { Glucose } \\
(\mathrm{mmol} / \mathrm{l})\end{array}$ & $\begin{array}{l}\text { Insulin } \\
\text { (pmol/l) }\end{array}$ & $\mathrm{K}_{\mathrm{G}}\left(\times 10^{-2}\right)$ & $\begin{array}{l}\text { Triglyceride } \\
\text { (mg/dl) }\end{array}$ & $\begin{array}{l}\text { Cholesterol } \\
(\mathrm{mmol} / \mathrm{l})\end{array}$ \\
\hline Controls $(n)$ & $\begin{array}{l}345 \pm 2 \\
(10)\end{array}$ & $\begin{array}{l}+78 \pm 4 \\
(10)\end{array}$ & $\begin{array}{l}4.7 \pm 0.2 \\
(8)\end{array}$ & $\begin{array}{l}35 \pm 5 \\
(8)\end{array}$ & $\begin{array}{l}4.9 \pm 0.6 \\
(8)\end{array}$ & $\begin{array}{l}91 \pm 11 \\
(8)\end{array}$ & $\begin{array}{l}1.0 \pm 0.1 \\
(8)\end{array}$ \\
\hline $\begin{array}{l}\mathrm{S} 15261 \\
(2.5 \mathrm{mg} / \mathrm{kg} \\
2 \times \text { daily })(n)\end{array}$ & $\begin{array}{l}349 \pm 4 \\
(10)\end{array}$ & $\begin{array}{l}+82 \pm 3 \\
(10)\end{array}$ & $\begin{array}{l}4.4 \pm 0.2 \\
(8)\end{array}$ & $\begin{array}{l}32 \pm 5 \\
(7)\end{array}$ & $\begin{array}{l}4.0 \pm 0.4 \\
(8)^{c}\end{array}$ & $\begin{array}{l}65 \pm 7 \\
(8)^{\mathrm{a}}\end{array}$ & $\begin{array}{l}1.5 \pm 0.1 \\
(10)\end{array}$ \\
\hline
\end{tabular}

S15261 was administered orally twice a day for 14 days. Statistical significance is indicated by ${ }^{\text {a }} p<0.05$ vs controls

In vitro studies. Pancreatic islets of Langerhans were isolated and incubated as described previously [23].

\section{Statistical analysis}

Data are presented as the mean \pm SEM and were analysed by two-way ANOVA followed by unpaired Student's $t$-test.

\section{Results}

Animals. The data presented here confirm that ageing Sprague-Dawley rats had elevated fasting plasma insulin, triglycerides and cholesterol levels when compared to young controls (compare the first lines in Tables 1 and 2). In addition, they were insulin resistant - as revealed by a decreased $\mathrm{K}_{\mathrm{G}}$ during an IVGTT and mildly hypertensive [12]. No obvious behavioural anomalies or other secondary effects were observed during treatment with S15261. Chronic treatment with the drug for 2 weeks resulted in a dose-dependent decrease in body weight in ageing animals (Table 1 ) which was not observed in young rats. At the highest dose, ageing rats lost approximately $3 \%$ of body weight by the end of the treatment.

Biological parameters. Treatment of ageing SpragueDawley rats with $\mathrm{S} 15261$ for 2 weeks led to dose-de- pendent decreases in plasma insulin (from $174 \mathrm{pmol} / \mathrm{l}$ to $99 \mathrm{pmol} / \mathrm{l})$, triglycerides (189 to $120 \mathrm{mg} / \mathrm{dl}$ ) and cholesterol (1.9 to $1.5 \mathrm{mmol} / \mathrm{l})$ levels (Table 1$)$. There was also a small but statistically significant reduction in plasma glucose (from 5.3 to $4.6 \mathrm{mmol} / \mathrm{l}$ ) at the highest dose of the drug. The compound had no effect on plasma lactate levels, even at the highest doses tested (controls: $1.9 \pm 0.1 \mathrm{mmol} / 1$ vs S15261: $1.6 \pm 0.2 \mathrm{mmol} /$ 1). In young rats the compound had no effect on any of these parameters, except for a reduction in plasma triglyceride levels (from 91 to $65 \mathrm{mg} / \mathrm{dl}$ ) (Table 2).

\section{Glucose tolerance tests}

Systemic. Chronic treatment of ageing rats with S15261 resulted in a dose-dependent increase in the $\mathrm{K}_{\mathrm{G}}$ during an IVGTT (Table 1), thereby demonstrating an improvement in glucose tolerance. Treatment with S15261 dose-dependently decreased basal insulin levels (down to a $43 \%$ reduction at $2.5 \mathrm{mg} / \mathrm{kg}$ ) and increased peak response to the glucose challenge, the latter reaching $348 \%$ relative to basal levels during the IVGTT at the dose of $2.5 \mathrm{mg} / \mathrm{kg}$ compared with $150 \%$ in untreated animals (Table 3 ). Moreover, a return to basal plasma insulin levels $28 \mathrm{~min}$ after the glucose challenge, which was absent in old untreated rats, was observed in the treated animals. 
Table 3. Plasma insulin levels during an IVGTT following chronic treatment with S15261 in ageing rats

\begin{tabular}{llll}
\hline & T0 & T4 & T28 \\
\hline Controls $(n)$ & $174 \pm 13$ & $437 \pm 33$ & $218 \pm 19$ \\
& $(20)$ & $(20)^{\mathrm{b}}$ & $(20)^{\mathrm{a}}$ \\
S15261 & $149 \pm 14$ & $414 \pm 30$ & $186 \pm 17$ \\
$\begin{array}{l}0.5 \mathrm{mg} / \mathrm{kg} \\
2 \times \text { daily) }(n)\end{array}$ & $(14)$ & $(14)^{\mathrm{b}}$ & $(14)$ \\
$\begin{array}{l}\text { S15261 } \\
(1.0 \mathrm{mg} / \mathrm{kg}\end{array}$ & $160 \pm 11$ & $395 \pm 30$ & $185 \pm 25$ \\
$2 \times$ daily) $(n)$ & $(15)$ & $(15)^{\mathrm{b}}$ & $(15)$ \\
S15261 & $99 \pm 10$ & $442 \pm 41$ & $114 \pm 10$ \\
$(2.5 \mathrm{mg} / \mathrm{kg}$ & $(11)^{\mathrm{c}}$ & $(11)^{\mathrm{b}}$ & $(11)^{\mathrm{c}}$ \\
$2 \times$ daily) $(n)$ & & & \\
\hline
\end{tabular}

Data are given for basal (TO, i. e. pre-challenge) insulin levels $(\mathrm{pmol} / \mathrm{l})$, at peak $(\mathrm{T} 4,4 \mathrm{~min})$ and at the time of return to basal (T28, $28 \mathrm{~min})$. The times were chosen from previous experiments. Statistical significance vs basal (T0) values within a group is indicated by: ${ }^{a} p<0.01 ;{ }^{b} p<0.001$. Statistical significance vs the same time point in the untreated group is indicated by ${ }^{c} p<0.001$

Table 4. Glucose disappearance rate during a portal infusion of S15261

\begin{tabular}{lll}
\hline $\begin{array}{l}\text { S15261 } \\
\left(\mu \mathrm{g} \cdot \mathrm{kg}^{-1} \cdot \mathrm{h}^{-1}\right)\end{array}$ & Before & After \\
\hline 15 & $3.8 \pm 0.5(5)$ & $3.9 \pm 0.6(5)$ \\
30 & $3.3 \pm 0.5(6)$ & $5.0 \pm 0.4(6)^{\mathrm{a}}$ \\
45 & $3.8 \pm 0.2(6)$ & $6.0 \pm 0.3(6)^{\mathrm{a}}$ \\
\hline
\end{tabular}

$\mathrm{K}_{\mathrm{G}}$ values are given as $\times 10^{-2}$. Statistical significance is indicated by ${ }^{a} p<0.001$. Details of the portal infusion are given in the Methods section. Numbers in parentheses are the number of animals per group. Note that each animal is its own control ("before" and "after" infusion of the drug)

Table 5. Glucose metabolism during a euglycaemic clamp in ageing Sprague-Dawley rats following chronic administration of $\$ 15261$

\begin{tabular}{lcc}
\hline & Controls & Treated \\
\hline $\begin{array}{l}\text { GIR } \\
\left(\mu \mathrm{mol} \cdot \mathrm{kg}^{-1} \cdot \mathrm{min}^{-1}\right)\end{array}$ & $1.28 \pm 0.1(15)$ & $1.52 \pm 0.05(16)^{\mathrm{a}}$ \\
$\mathrm{SSIL}(\mathrm{nmol} / \mathrm{l})$ & $9.7 \pm 0.4(15)$ & $8.2 \pm 0.3(16)$ \\
$\mathrm{HGP}$ & & \\
$\left(\mu \mathrm{mol} \cdot \mathrm{kg}^{-1} \cdot \mathrm{min}^{-1}\right)$ & $0.36 \pm 0.02(11)$ & $0.30 \pm 0.02(11)$ \\
$\begin{array}{l}\text { Insulin clearance rate } \\
\left(\mathrm{ml} \cdot \mathrm{kg}^{-1} \cdot \mathrm{min}^{-1}\right)\end{array}$ & $14.1 \pm 0.6(15)$ & $15.6 \pm 0.6(16)$ \\
\hline
\end{tabular}

S15261 was administered at $2.5 \mathrm{mg} / \mathrm{kg}$ twice daily orally for 14 days. Data are presented as means + SEM. Statistical significance is indicated by ${ }^{a} p<0.05$ vs control values. Numbers in brackets are the number of animals per group

Portal administration. In order to examine whether the peripheral action of S15261 was focused on the liver we conducted glucose tolerance tests by portal administration of the compound. At weak doses (15$45 \mu \mathrm{g} \cdot \mathrm{kg}^{-1} \cdot \mathrm{h}^{-1}$ ) S15261 resulted in dose-dependent increases in the $\mathrm{K}_{\mathrm{G}}$ during the IVGTT (Table 4). In
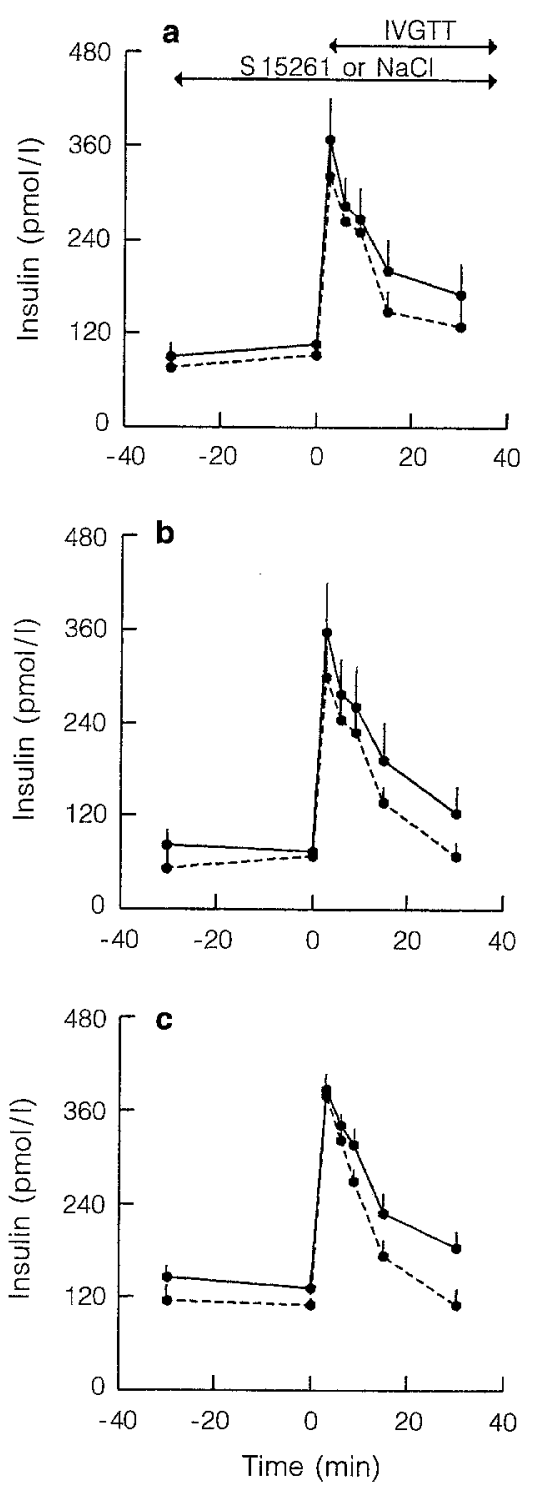

Fig. 2a-c. Effect of an intraportal infusion of S15261 on the insulin secretory response to an IVGTT. The results are the mean \pm SEM for 5-6 rats (see Table 4 for details), where each animal serves as its own control. The control infusion was $0.9 \%$ $\mathrm{NaCl}(-)$. The concomitant $\mathrm{K}_{\mathrm{G}}$ values are given in Table 4 Broken lines indicate S15261 groups; a $0.015 \mathrm{mg} \cdot \mathrm{kg}^{-1} \cdot \mathrm{h}^{-1}$, $n=5 ; \mathbf{b} 0.030 \mathrm{mg} \cdot \mathrm{kg}^{-1} \cdot \mathrm{h}^{-1}, n=6 ; \mathbf{c} 0.045 \mathrm{mg} \cdot \mathrm{kg}^{-1} \cdot \mathrm{h}^{-1}, n=6$

addition the pancreatic response to the glucose challenge was also improved (Fig. 2), showing a faster return to baseline levels. Therefore, the effects of S15261 on glucose tolerance observed following chronic treatment can also be shown when the compound is given intraportally to naive animals.

Glucose clamp. A euglycaemic hyperinsulinaemic clamp was performed following 2 week treatment of ageing rats with S15261. The data presented in Table 5 demonstrate an improvement in insulin sensitivity with the drug. Thus, the GIR required to maintain euglycaemia was increased by $20 \%$, showing an increase in glucose metabolism. SSIL achieved during 
administration of $24 \mathrm{mU} \cdot \mathrm{kg}^{-1} \cdot \min ^{-1}$ decreased by $15 \%$ in the drug-treated group. Basal hepatic glucose production and insulin clearance rate were unchanged. These data demonstrate that treatment with S15261 results in an increased peripheral sensitivity to insulin.

Glycogen metabolism. In order to identify the potential molecular mechanisms for the metabolic effects of S15261, and given the improvement in glucose tolerance observed by portal administration of the drug, we examined hepatic glycogen metabolism following 2 weeks of treatment (Table 6). Total glycogen levels were not altered following the treatment with S15261 and glycogen synthase activity was also unchanged. In contrast, a decrease of $25 \%$ in the active form of glycogen phosphorylase without a change in the total activity was observed. No changes were observed in glucokinase activity.

Blood pressure. In order to test the hypothesis that S15261 may be useful therapy for the overall features of the insulin resistance syndrome, we tested the effects of chronic treatment on mean arterial blood pressure (Table 7). We have recently shown that ageing Sprague-Dawley rats exhibit mild hypertension, reaching a difference of $25 \mathrm{~mm} \mathrm{Hg}$ when compared with young controls [12]. Treatment for 2 weeks with S15261 resulted in dose-dependent decreases in basal arterial blood pressure $(8 \%$ at $2.5 \mathrm{mg} / \mathrm{kg}$ twice per day $(p<0.05)$ and $11 \%$ at $12.5 \mathrm{mg} / \mathrm{kg}$ twice per day $(p<0.01))$. S15261 was devoid of any hypotensive activity when administered acutely either orally or intravenously (data not shown).

\section{Studies on the mechanism of action of $\$ 15261$}

Effects of acute administration of S15261. An acute administration, either orally or intravenously, of S15261 had no effect on plasma glucose and insulin levels even at high doses. Thus, at the dose of S15261 of $10 \mathrm{mg} / \mathrm{kg}$ given intravenously, plasma glucose levels were $4.4 \pm 0.2 \mathrm{mmol} / \mathrm{l}$ at basal levels, and changed to $4.2 \pm 0.4,4.2 \pm 0.4$, and $4.2 \pm 0.4 \mathrm{mmol} / 1,15,30$ and $60 \mathrm{~min}$ after administration of the compound, whilst insulin levels were $150.0 \pm 13.0,192.0 \pm 25.0$, $170.0 \pm 22.0,178.0 \pm 16.0 \mathrm{pmol} / 1$ at the same time points. Data for oral administration showed the same profile (not shown).

Insulin secretion in isolated islets of Langerhans. In islets isolated from normal Sprague-Dawley rats previously untreated with the drug, S15261 had no effect on insulin secretion (Table 8).

Receptor binding profile of S15261. S15261 does not appear to show any specificity for $\alpha$ - or $\beta$-adrenergic,
Table 6. Effects of chronic administration of S15261 on hepatic glycogen content and on some enzymes of glucose and glycogen metabolism in ageing Sprague-Dawley rats

\begin{tabular}{lcc}
\hline & Controls & Treated \\
\hline Glycogen (g/100 g liver) & $6.9 \pm 0.4$ & $6.1 \pm 0.4$ \\
Glycogen synthase & $0.31 \pm 0.04$ & $0.31 \pm 0.04$ \\
active & $1.5 \pm 0.1$ & $1.3 \pm 0.1$ \\
total & $20 \pm 3$ & $23 \pm 2$ \\
$\%$ active & & \\
Glycogen phosphorylase & $33.0 \pm 2.4$ & $25.2 \pm 2.0^{\mathrm{a}}$ \\
active & $201.0 \pm 10.0$ & $188 \pm 18$ \\
total & $17 \pm 2$ & $14 \pm 1$ \\
$\%$ active & $2.6 \pm 0.1$ & $2.5 \pm 0.2$ \\
Glucokinase & $1.4 \pm 0.1$ & $1.4 \pm 0.1$ \\
Hexokinase &
\end{tabular}

S15261 was administered at $2.5 \mathrm{mg} / \mathrm{kg}$ twice daily orally for 14 days. Data are given as units ( $\mu \mathrm{mol}$ substrate utilised per min per $g$ liver) and are the means \pm SEM of 10 animals per group. Statistical significance is indicated by ${ }^{a} p<0.05$ vs controls

Table 7. Effects of chronic administration of S15261 on blood pressure in ageing Sprague-Dawley rats

\begin{tabular}{ll}
\hline & $\begin{array}{l}\text { Blood pressure } \\
(\mathrm{mmHg})\end{array}$ \\
\hline Untreated controls & $114.7 \pm 3.4$ \\
S15261, $2.5 \mathrm{mg} / \mathrm{kg} 2 \times$ daily & $105.0 \pm 3.4^{\mathrm{a}}$ \\
S15261, $12.5 \mathrm{mg} / \mathrm{kg} 2 \times$ daily & $102.1 \pm 2.8^{\mathrm{b}}$ \\
\hline
\end{tabular}

Male Sprague-Dawley rats at least 52 weeks old were treated every day for 15 days at the doses indicated. Mean arterial pressure was measured as described in Methods. Data are presented as means \pm SEM. Statistical significance is indicated by ${ }^{\mathrm{a}} p<0.05 ;{ }^{\mathrm{b}} p<0.01$

Table 8. Effects of S15261 on insulin secretion in isolated islets

\begin{tabular}{lcc}
\hline \multicolumn{3}{c}{ Glucose $(\mathrm{mmol} / \mathrm{l})$} \\
\hline S15261 $(\mu \mathrm{mol} / \mathrm{l})$ & 2.8 & 16.7 \\
None & $45.0 \pm 7.4$ & $151.0 \pm 24.0$ \\
10 & $62.8 \pm 21.0$ & $134.0 \pm 28.3$ \\
100 & $66.0 \pm 21.5$ & $124.6 \pm 22.0$ \\
\hline
\end{tabular}

Islets were prepared as described in the Methods section and incubated in the presence of glucose at the concentrations indicated. S15261 was dissolved in dimethylsulphoxide to a final concentration of $1 \%$ in the incubation media. Control incubations ("None") also included $1 \%$ dimethylsulphoxide. Insulin secretion is given as pmol $\cdot$ islet $^{-1} \cdot \mathrm{h}^{-1}$. Data are presented as means \pm SEM for $6-8$ observations

serotoninergic, dopaminergic, opioid or excitatory amino acid receptors (data not shown).

\section{Discussion}

Insulin resistance appears to be a common underlying feature of hypertension, impaired glucose tolerance, obesity and diabetes. Drugs used to treat these conditions have different effects on insulin resistance. In 
searching for drugs that could be used as an overall treatment of the insulin resistance syndrome (i.e. act upon several of the features of the syndrome) we identified the compound presented in this paper. S15261 does not belong to any of the classes of agents currently under study for the treatment of insulin resistance. It is not a thiazolidinedione derivative, nor a biguanide. Indeed the compound had no effects on plasma lactate levels. Although other compounds have also been studied, S15261, has proved to be a leading example of its class.

In the present study we have used ageing SpragueDawley rats as a model of the insulin resistance syndrome. The characteristics of the syndrome presented in our animals - hyperlipidaemia, hyperinsulinaemia, decreased glucose tolerance, decreased insulin sensitivity and mild hypertension - are the same as those described in humans. This cluster of changes is not inherited and may be a consequence of increased body weight, changes in body fat composition and/or physical inactivity. Whilst rats may become insulin resistant with age, few become spontaneously diabetic. This is in agreement with the hypothesis that the onset of diabetes requires both insulin resistance and a defective insulin secretory response. We have observed in the past that some of our elderly rats do indeed become spontaneously diabetic, but the incidence is very low (less than $4 \%$ ) (Duhault, Boulanger and Ravel, unpublished observations).

The effects of S15261 on glucose tolerance were observed $24 \mathrm{~h}$ after the last administration of the drug, and therefore must represent a long-term normalization of glucose metabolism induced by the compound. The improvement in glucose tolerance and the lowering of triglyceride levels following the treatment with S15261 seemed to be related, since they were observed even at doses of the drug that had no effect on other parameters. The increase in glucose tolerance correlated with an improved pancreatic response to glucose, and an increased peripheral insulin sensitivity, which could be related to an increase in peripheral glucose metabolism.

The physiological mechanisms responsible for the effects of S15261 on chronic administration are therefore not related to body-weight loss which was only observed at the highest dose. It was also at this dose that a mild decrease in plasma glucose was observed. We therefore suggest that two separate events are observed during chronic administration of S15261. On the one hand, at low doses the compound decreases circulating triglycerides and improves $\mathrm{K}_{\mathrm{G}}$, whilst, on the other hand, at much higher doses different mechanisms take place leading to body-weight loss and other metabolic effects.

In order to assess whether the compound had acute metabolic actions in vivo we investigated the effects of S15261 when administered by an intraportal route to young animals. The compound produced an increase in glucose disposal rates and an improved insulin secretory response, as had been observed following chronic administration. These data suggest that the metabolic effects of S15261 are not related to the reduction in body weight observed in treated animals.

The mechanism action of S15261 is unknown. We have attempted to address this issue in a variety of ways. Firstly, S15261 does not alter insulin secretion in vivo, whether it is following chronic or acute administration. Furthermore, in in vitro studies in islets isolated from normal rats, S15261 did not stimulate insulin secretion either. We would therefore argue that the primary effect of the drug is not located in the pancreas.

Secondly, the data obtained from the euglycaemic clamp showed no effects of the drug on HGP, thus suggesting that a hepatic site of action of the drug is unlikely. Moreover, no major changes in the activity of key hepatic enzymes regulating glucose and glycogen metabolism were observed. It is difficult to interpret the physiological relevance of a minor change in the active form of glycogen phosphorylase since the percentage active form was unchanged.

However, the effects of an intraportal administration of S15261 on glucose metabolism and the pancreatic response during an IVGTT are of great interest in this context. In the absence of hepatic effects of the drug on chronic administration, the data on intraportal administration must therefore be interpreted in terms of either insulin clearance (no effect under the clamp), fatty acid oxidation (not measured) or eventual effects on neurotransmitter control of hepatic glucose metabolism and/or insulin secretion. To this end we assessed the receptor binding profile of S15261. The absence of any specificity for $\alpha$ - or $\beta$ adrenergic, serotoninergic, dopaminergic, opioid or excitatory amino acid receptors suggests that other systems, which we have not as yet identified, must be implicated in the molecular site of action of S15261.

Thirdly, since there was an improvement of $20 \%$ in peripheral sensitivity to insulin without any modification of hepatic glucose metabolism, an improved sensitivity of skeletal muscle and/or adipose tissue to insulin is an obvious possibility. These data coupled to those obtained during the intraportal infusion of the compound suggest that S15261 may stimulate glucose uptake in peripheral tissues. Studies on the effect of S15261 on insulin sensitivity in adipose tissue and skeletal muscle in vitro are underway.

It is most important to point out that the effects of S15261 to improve insulin resistance are revealed primarily following chronic administration, and that, as far as plasma glucose and/or insulin levels are concerned, the drug appears inactive after acute administration in vivo. In this context the data obtained in young animals following chronic administration are interesting, as they only revealed a decrease in plasma triglyceride levels. It is not inconceivable that the pri- 
mary site of action of S15261 under chronic administration is lipid turnover, and that the improvement in insulin resistance is a consequence of these changes coupled with a potential stimulation of glucose uptake. Experiments to evaluate this hypothesis need to be undertaken.

Chronic treatment with $\mathrm{S} 15261$ resulted in a normalization of blood pressure in the ageing SpragueDawley rats. We believe this is likely to be the result of both changes in body weight and plasma insulin levels, and thus related to the overall improvements in the metabolic parameters.

In summary the activity of S15261 to increase insulin sensitivity and decrease body weight, plasma lipids, plasma insulin and normalize blood pressure suggests that this compound could be of benefit in the treatment of patients with insulin resistance.

Acknowledgements. We are indebted to Ms. S.Berger, Mr. O.Broux, Ms. S.Challal, and Ms. C.Deheegher-Bourrier for technical assistance, to Dr. B. Robert for the islet data, to Drs. E. Giesen and A. Lombet for receptor binding studies, to Ms. S. Laurin for statistical analyses, and to Ms. J. Chauvigné for secretarial and administrative work.

\section{References}

1. De Fronzo RA, Ferrannini E (1991) Insulin resistance: a multifaceted syndrome responsible for NIDDM, obesity, hypertension, dyslipidaemia and atherosclerotic cardiovascular disease. Diabetes Care 14: 173-195

2. Reaven GM (1988) Role of insulin resistance in human disease. Diabetes 37: 1595-1607

3. Modan M, Halkin H, Almog S (1985) Hyperinsulinaemia: a link between hypertension, obesity and glucose intolerance. J Clin Invest 75: 809-817

4. Ferrannini E, Buzzigoli G, Bonadonna R et al (1987) Insulin resistance in essential hypertension. N Eng J Med 317: 350 357

5. Lithell OH, Pollare T, Berne C (1990) Insulin sensitivity in newly detected hypertensive patients: influence of Captopril and other antihypertensive agents on insulin sensitivity and related biological parameters. J Cardiovasc Pharmacol 15: 546-552

6. Pollare T, Lithell OH, Berne C (1989) A comparison of the effects of hydrochlorothiazide and Captopril on glucose and lipid metabolism in patients with hypertension. N Eng $J$ Med 321: 868-873

7. Bailey CJ (1992) Biguanides and NIDDM. Diabetes Care 15: 755-773
8. Bressler R, Johnson D (1992) New pharmacological approaches to the therapy of NIDDM. Diabetes care 15: 792805

9. Duhault J, Boulanger M, Beregi L, Sicot N, Bouvier F (1976) $70 \mathrm{SE}$ : a new type of hypolipemic agent. Comparative assays in rats. Atherosclerosis 23: 63-72

10. Reaven GM (1991) Insulin resistance, hyperinsulinaemia, hypertriglyceridaemia, and hypertension: parallels between human disease and rodent models. Diabetes Care 14: 195202

11. De Fronzo RA (1979) Glucose intolerance and aging: evidence for tissue insensitivity to insulin. Diabetes 28: 10951101

12. Reaven E, Wright D, Mondon CE, Solomon HH, Reaven GM (1983) Effect of age and diet on insulin secretion and action in the rat. Diabetes 32:175-180

13. Feletou M, Moreau N, Boulanger M, Duhault J (1993) Effect of aging and drug-induced weight reduction on rat vascular reactivity. J Cardiovasc Pharmacol 21: 120-127

14. Strubbe JH, Wolsink JG, Schutte DM, Balkan B, Prins DJA (1989) Hepatic portal and cardiac infusion of CCK-8 and glucagon induce different effects on feeding. Physiol Behaviour 4: 643-646

15. Smith D, Rassetti C, Ferrannini E et al. (1987) In vivo glucose metabolism in the awake rat: tracer and insulin clamp studies. Metabolism 36: 1167-1174

16. Nishimura H, Kuzuya H, Okamoto $M$ et al. (1988) Change of insulin action with aging in conscious rats determined by euglycemic clamp. Am J Physiol 254: E92-E98

17. Kergoat M, Portha B (1985) In vivo hepatic and peripheral insulin sensitivity in rats with non-insulin dependent diabetes induced by streptozotocin. Assessment with the insulin-glucose clamp technique. Diabetes 34: 1120-1126

18. Steele R (1959) Influence of glucose loading and of injected insulin on hepatic glucose output. Ann N Y Acad Sci 82: 420-430

19. De Fronzo RA, Jordan DT, Reubin A (1979) Glucose clamp technique: a method for quantifying insulin secretion and resistance. Am J Physiol 237: E214-E223

20. Van de Werve G, Sestoft L, Falke M, Kristensen LO (1984) The onset of liver glycogen synthesis in fasted-refed rats. Diabetes 33: 944-949

21. Golden S, Wals PA, Katz J (1977) An improved procedure for the assay of glycogen synthase and phosphorylase in rat liver homogenate. Anal Biochem 77: 436-445

22. Van Schaftingen E (1989) A protein from rat liver confers to glucokinase the property of being antagonistically regulated by fructose-6-phosphate and fructose-1-phosphate. Eur J Biochem 179: 179-184

23. Lacy P, Koskanovsky M (1967) Method for the isolation of intact islets of Langerhans from the rat pancreas. Diabetes 16: 35-39 